Canadian Journal of Higher Education

Revue canadienne d'enseignement supérieur

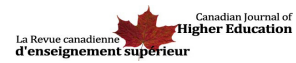

\title{
Applying Indigenizing Principles of Decolonizing Methodologies in University Classrooms
}

\author{
Dustin William Louie, Yvonne Poitras-Pratt, Aubrey Jean Hanson et Jacqueline \\ Ottmann
}

Volume 47, numéro 3, 2017

URI : https://id.erudit.org/iderudit/1043236ar

DOI : https://doi.org/10.7202/1043236ar

\section{Aller au sommaire du numéro}

\section{Éditeur(s)}

Canadian Society for the Study of Higher Education

ISSN

2293-6602 (numérique)

Découvrir la revue

Citer cet article

Louie, D., Poitras-Pratt, Y., Hanson, A. \& Ottmann, J. (2017). Applying Indigenizing Principles of Decolonizing Methodologies in University Classrooms. Canadian Journal of Higher Education / Revue canadienne d'enseignement supérieur, 47(3), 16-33. https://doi.org/10.7202/1043236ar
Résumé de l'article

La présente étude de cas examine le travail actuel de programmes d'éducation d'une université canadienne en matière d'indigénisation. En effet, au Canada, l'enseignement académique a été dominé par les épistémologies occidentales, qui ont dévalué les systèmes de connaissance autochtones et ont jeté les bases d'une marginalisation continue de l'histoire, des étudiants, des communautés et des cultures autochtones. Les institutions d'enseignement supérieur doivent s'éloigner de la vision étroite trop souvent utilisée pour comprendre l'éducation. Elles ont plutôt besoin de mettre en place des stratégies d'indigénisation afin de contrer la monopolisation systémique des connaissances et des communications. Les facultés d'éducation tiennent le rôle principal en intégrant les systèmes de connaissance autochtones dans leurs programmes et en embauchant des chercheurs autochtones. Ainsi, inspirés par les 25 principes d'indigénisation articulés par la chercheuse maōri Linda Tuhiwai Smith (2012), quatre chercheurs autochtones de l'ouest du Canada ont documenté des pratiques de décolonisation efficaces pour l'enseignement, de même que des interactions et un apprentissage qui reflètent les valeurs et orientations autochtones dans leurs pratiques pédagogiques.
Copyright (c) Dustin William Louie, Yvonne Poitras-Pratt, Aubrey Jean Hanson, Jacqueline Ottmann, 2017

Attribution-NonCommercial-No Derivative Works 2.5 Canada
Ce document est protégé par la loi sur le droit d'auteur. L'utilisation des services d'Érudit (y compris la reproduction) est assujettie à sa politique d'utilisation que vous pouvez consulter en ligne.

https://apropos.erudit.org/fr/usagers/politique-dutilisation/ 


\title{
Applying Indigenizing Principles of Decolonizing Methodologies in University Classrooms
}

Dustin William Louie, Yvonne Poitras Pratt, Aubrey Jean Hanson, Jacqueline Ottmann University of Calgary

\begin{abstract}
This case study examines ongoing work to Indigenize education programs at one Canadian university. The history of the academy in Canada has been dominated by Western epistemologies, which have devalued Indigenous ways of knowing and set the grounds for continued marginalization of Indigenous students, communities, cultures, and histories. We argue that institutions of higher learning need to move away from the myopic lens used to view education and implement Indigenizing strategies in order to counteract the systemic monopolization of knowledge and communication. Faculties of education are taking a leading role in Canadian universities by hiring Indigenous scholars and incorporating Indigenous ways of knowing into teacher education courses. Inspired by the 25 Indigenous principles outlined by Maōri scholar Linda Tuhiwai Smith (2012), four Indigenous faculty members from Western Canada document effective decolonizing practices for classroom experience, interaction, and learning that reflect Indigenous values and orientations within their teaching practices.
\end{abstract}

\section{Résumé}

La présente étude de cas examine le travail actuel de programmes d'éducation d'une université canadienne en matière d'indigénisation. En effet, au Canada, l'enseignement académique a été dominé par les épistémologies occidentales, qui ont dévalué les systèmes de connaissance autochtones et ont jeté les bases d'une marginalisation continue de l'histoire, des étudiants, des communautés et des cultures autochtones. Les institutions d'enseignement 
supérieur doivent s'éloigner de la vision étroite trop souvent utilisée pour comprendre l'éducation. Elles ont plutôt besoin de mettre en place des stratégies d'indigénisation afin de contrer la monopolisation systémique des connaissances et des communications. Les facultés d'éducation tiennent le rôle principal en intégrant les systèmes de connaissance autochtones dans leurs programmes et en embauchant des chercheurs autochtones. Ainsi, inspirés par les 25 principes d'indigénisation articulés par la chercheuse maōri Linda Tuhiwai Smith (2012), quatre chercheurs autochtones de l'ouest du Canada ont documenté des pratiques de décolonisation efficaces pour l'enseignement, de même que des interactions et un apprentissage qui reflètent les valeurs et orientations autochtones dans leurs pratiques pédagogiques.

With its historic roots in the Anglo-European Enlightenment, the modern university is the epitome of "Western" institutions, having played a key role in the spread of empire and the scientific study and colonization of Indigenous peoples and cultures. The increasing presence of Indigenous professors and students in universities and the transnational movement for Indigenous sovereignty and social justice have prompted many academics and institutions to contemplate what "Indigenizing" the university could mean in practice (Anuik \& Gillies, 2012; den Heyer, 2015; Pidgeon, Archibald, \& Hawkey, 2014). This movement bears similarities to broader anti-racist perspectives expressed by racially minoritized academics (Spafford, Nygaard, Gregor, \& Boyd, 2006). The history of the academy in Canada has been dominated by Western epistemologies that have devalued Indigenous ways of knowing as a matter of course. This institutional history has set the grounds for continued marginalization of Indigenous communities, cultures, and histories (Battiste, 2002, 2013; Sensoy \& DiAngelo, 2012). The well-being of Indigenous students has also been compromised by the impacts of colonization on processes and content in contemporary education systems (Battiste, 1998; 2013; Cajete, 1994; Little Bear, 2000). In our experience, the same impacts now extend to Indigenous faculty members who hold community values and orientations within their teaching practices. Consequently, decolonizing and Indigenizing postsecondary education entails transforming imperialist and assimilative frameworks, validating Indigenous knowledges and epistemologies, and asserting the presence and humanity of Indigenous peoples (Battiste, 2013; Smith, 2012).

This article describes a case study of the Indigenization of university pedagogies, drawn from our experiences as Indigenous faculty members working in the Werklund School of Education at the University of Calgary. We write together as a diverse group; each of us brings a unique perspective to our shared goal of integrating Indigenous perspectives into our work through our positioning as First Nations and Métis scholars. We contend that institutions of higher learning need to move away from the myopic lens used to view education and implement Indigenizing pedagogies in order to counteract the systemic monopolization of knowledge and communication. We are beginning to see faculties of education taking a leading role in Canadian universities by hiring Indigenous academics and incorporating Indigenous content and ways of knowing into teacher education courses. Given the growing corpus of Indigenous educators working in this field, as well as the ever-mounting need for reconciliation between Indigenous and non-Indigenous peoples, we believe it is time to share wise practices based on Indigenous scholarship. 
We have opted to use our collective experiences as Indigenous faculty members within an illustrative case study (Merriam, 1998; Nath, 2005). As Indigenous scholars, we recognize the importance of maintaining a holistic orientation and, as Yin (2009) asserts, "The distinctive need for case studies arises out of the desire to understand complex social phenomena ... [and] allows investigators to retain the holistic and meaningful characteristics of real-life events" (p. 4). Our intent is to contribute to the foundation of Indigenous pedagogies. Collecting and reporting on the Indigenizing practices of a single faculty is not intended to provide the standard from which others should operate. Our contribution to the field is to document some promising alternatives to the limited philosophical diversity in institutions of higher learning by offering pedagogical practices framed within the work of Maōri scholar Linda Tuhiwai Smith (2012). Smith's (2012) text was created for international application, and foundational works by Canadian Indigenous scholars (Battiste, 2013; Goulet \& Goulet, 2014; Kovach, 2010) have adopted her principles.

In what follows, we use the 25 Indigenous projects presented in Smith's (2012) Decolonizing Methodologies as inspirational principles for reimagining our pedagogy within university courses. If the goal of Smith's methodology is to articulate research strategies that decolonize populations and promote Indigenous self-determination, we contend that the same methods might achieve comparable results in university classrooms. To test this claim, we will first establish that solely relying on Western epistemologies and methodologies in university classrooms is further marginalizing Indigenous students and educators (Battiste, 2013; Ermine, 1995; Little Bear, 2011; Smith, 2012). To provide a measure of the current standards applied within university classrooms, we will examine teacher evaluation tools used in the western Canadian postsecondary context. Second, we will show how Smith's (2012) principles translate into pedagogy, using selected principles and examples from each author's classroom practices.

\section{Deficits Created through the Monopoly of Western Epistemology}

It would be misguided to posit that low levels of educational achievement are attributable to problems intrinsic to Indigenous peoples and cultures, instead of acknowledging the deficiencies of postsecondary institutions (Little Bear, 2009). The difficulties faced by Indigenous students in Canadian universities, evidenced by lower rates of achievement and completion (Hardes, 2013; Statistics Canada, 2011), primarily stem from well-documented institutional and cultural barriers that set the longitudinal grounds for educational marginalization (Association of Canadian Deans of Education, 2010; Battiste, 2013; Schissel \& Wotherspoon, 2003; Truth and Reconciliation Commission of Canada, 2015). Postsecondary institutions have not done enough to create a diverse educational model to eliminate discrimination. The tendency of most university instructors to employ methods of instruction firmly situated within the epistemological structure of the dominant culture exacerbates what, for many Indigenous students, is a lifelong process of institutional marginalization by and alienation from mainstream Western schooling. The same now applies to Indigenous faculty seeking tenure.

\section{Teacher Evaluation Tools}

Despite meaningful shifts in pedagogy in recent decades, lecture-style instruction is still prominent in Canadian university classrooms, reflecting the ethos of an Industrial 
Age model with the "importance of traditional disciplinary knowledge and the need to sort people" (Gilbert, 2005, p. 7) at its core. In order to provide insight into the value attributed to certain instructional strategies in higher education, we examine here the Universal Student Ratings of Instruction (USRI), an evaluation tool used by a number of universities in Alberta to assess teaching (Beran, Violato, Kline, \& Frideres, 2005; University of Alberta, 2015). The USRI focuses on twelve indicators of teacher effectiveness:

1. Overall instruction,

2. Enough detail in the course outline,

3. Course consistent with the outline,

4. Content well organized,

5. Student questions responded to,

6. Communicated with enthusiasm,

7. Opportunities for assistance,

8. Students treated respectfully,

9. Evaluation methods fair,

10. Work graded in reasonable time,

11. "I learned a lot in this course," and,

12. Support materials helpful. (USRI Review Committee, 2003)

The questions on the USRI create expectations for both students and teachers on what comprises "good" education. We argue that the categories comprising the USRI leave little room for considerations such as whether the instruction enabled diverse ways of accessing learning or was culturally responsive.

As an evaluative instrument and a barometer of what is considered valuable in University of Calgary courses, Beran, Violato, Kline, and Frideres (2005) found that USRI scores influence which classes students select and which faculty members are promoted by administration. Interestingly, the same study found that professors rarely modify their teaching in response to the USRIs: this finding leads us to ask if these rating systems really drive models of instruction. We argue that ratings systems shape instruction much like evolution in an ecosystem: ratings do not change the makeup of individuals during their lives, but promote those who naturally fit within the system. Despite the ubiquity of USRIs and their utility for institutional decision-makers, some faculties have shown encouraging signs of recognizing value in alternative teaching models, including those of Indigenous instruction. These innovations are not, however, afforded institutional value. A study by the USRI Review Committee (2003) argued that USRIs "cannot be the only source of information for evaluating instructors' teaching" (p. 7). Our point is that standardized metrics for the assessment of quality university teaching have the effect of defining "what will count" as quality for students, professors, and university corporate managers seeking "evidence" of quality. This outmoded standard for defining and assessing quality instruction has the effect of silencing and devaluing other ways of teaching and learning. We believe that if institutions of learning truly want to promote diversity of pedagogical models, they must place value on other ways of knowing.

As a counterpoint, we might consider Blackfoot scholar, Pepion (1999), who investigated traditional learning and found principles critical to education for Blackfoot people, such as learning from origin stories, Elders, extended family and community, holistic concepts, the environment, spirituality, revitalization, language, and philosophy. Indigenous 
scholars are not advocating cultural rites of passage as compulsory for non-Indigenous students, but there is an opportunity to find ethical spaces between cultures that honour a multitude of learning traditions (Ermine, 2007). Applying Blackfoot concepts is one example of the wealth of resources available to educators in contemporary education systems to provide mechanisms of evaluation and pedagogy that explore beyond Western traditions.

It is important to recognize that Western models of education are not all positivistic perspectives and factory-model instruction; critiques of Canadian systems need to include acknowledgement of bold theorists attempting to shift the current landscape. Non-Indigenous scholars are working to dismantle unresponsive pedagogy by employing student-centred (Rogers \& Freiberg, 1994) critical education (Giroux, 2014a, 2014b) and constructivist paradigms (Gredler, 2005), among others. Reimagined systems, schools, and classrooms do exist but are far from standard in mainstream western Canadian universities (Kincheloe \& Steinberg, 2007). Indigenous academics, such as Battiste (2013), remind us to avoid the temptation of including Indigenous pedagogies under the banner of Western critical theories. Instead, we should heed the guidance of Elder Dr. Reg Crowshoe, who conceptualizes Indigenous and non-Indigenous theories as being parallel to one another (Crowshoe \& Manneschmidt, 2002), or heed the counsel of Ermine (2007) in imagining an ethical space in between worldviews.

\section{Decolonizing Methodologies as a Teaching Model}

Smith's (2012) Decolonizing Methodologies is a foundational work of Indigenous methodology and, notably, has maintained its significance for almost 20 years since its original publication in 1999 (Porsanger, 2004). Smith's (2012) perspectives echo what has been understood in Indigenous communities across Canada for generations. Decolonizing Methodologies asserts that Western researchers have maintained oppressive relationships with Indigenous populations through methodologies that pay no heed to Indigenous traditions and make no effort to engage Indigenous communities as equals. Research, Smith (2012) argues, is always a political act and has been used to the benefit of the dominant culture by modelling the core intellectual practices of colonization: defining terms, naming, categorizing and hierarchizing, "disciplining," and, ultimately, assigning value. Smith lays out a methodological philosophy for decolonizing that promotes selfdetermination for Indigenous people. Much like education, Western research systematically ignores Indigenous ways of knowing by claiming that research findings will benefit Indigenous communities. What these researchers are missing is that the colonial relationship of asymmetrical power maintained in classical and empirical research studies often causes more damage than any possible benefit. Moreover, these findings often reflect Western epistemologies: the logic behind the recommendations is incongruent with Indigenous ways of knowing, and the resultant "reforms," irrespective of their liberal and progressive intents, hold little hope for meaningful change.

In Decolonizing Methodologies, Smith (2012) creates a conceptual model for an Indigenous research agenda. The framework is circular, with four "tides" or layers: survival, recovery, development, and self-determination (p. 121). The circle has four directions: mobilization, healing, decolonization, and transformation (p. 121). This model forms the goals of Indigenous research, the steps that need to be experienced to reach self-determination, and the processes that can usher in transformational change. This conceptual 
framework can be viewed as the foundation of Smith's (2012) vision for Indigenous research, where "the agenda is focused strategically on the goal of self-determination of indigenous peoples" (p. 120).

Yet there is nothing explicitly limiting this model to research per se. Smith's (2012) conceptual model helps the reader understand, philosophically, the shift required for Indigenous methodologies to be enacted. It is our belief that the four layers and directions can be effectively and strategically applied within an educational milieu of teaching and learning-much as they are in research. In this way, hitherto dominant models of educational practice can be transformed through Indigenous understandings. The connection between research, which produces new knowledge, and the essence of education, which creates, disseminates and shares knowledge, highlights the continuum within which they operate. Further, it is worth recalling that a cornerstone of the traditional Western university that is used to judge the contributions of the professoriate is the creation and contribution of new knowledge. To create the "new," universities have increasingly adopted the rhetoric of multinational corporations with policies mandating the teaching of "generic capacities" that include entrepreneurship, collaborative work, intercultural communication, and other commercial undertakings (Altbach, 2015). At the same time, the university seeks knowledge creation by asserting canonical traditions of science, scholarly inquiry, and empirical research-which, we have noted, are part of a history of colonization that precludes Indigenous engagement and collaboration (Stonechild, 2006). What we propose here is a reformation of pedagogy in higher education through the use and valuing of Indigenous epistemologies and ways of knowing.

This transformation in education requires moving beyond the superficial inclusion of Indigenous content. In our view, it entails embedding sustainable Indigenous principles within postsecondary institutions. In this case study, we extend Smith's (2012) framework for decolonizing research into the realm of teaching by demonstrating how our own pedagogical practices are, in fact, ways of applying her principles. The 25 principles are as follows:
1. Claiming,
10. Reading,
19. Networking,
2. Testimonies,
11. Writing,
20. Naming,
3. Storytelling,
12. Representing,
21. Protecting,
4. Celebrating survival,
13. Gendering,
22. Creating,
5. Remembering,
14. Envisioning,
23. Negotiating,
6. Indigenizing,
15. Reframing,
24. Discovering, and
7. Intervening,
16. Restoring,
25. Sharing.
8. Revitalizing,
17. Returning,
9. Connecting,
18. Democratizing,

While Smith delineates 25 "Indigenous projects," we have envisioned these projects as principles meaningfully rooted in our own beliefs about teaching. We agree with Smith (2012) that a program of engagement is required to become "very strategic in its purpose and activities and relentless in its pursuit of social justice" (p. 143).

The necessity of being strategic in decolonizing work is clear, and several Canadian universities, including the University of British Columbia (2012) and the University of Alberta 
(2011), have voiced their desire to incorporate Indigenous knowledge into education and other faculties. There are no limitations on the application of Smith's principles in education, which could become a fundamental aspect of an Indigenized faculty. The mistake often made by university faculties is to ignore the value that Indigenous methods of education could bring to standardized Western curricula. Isolating Indigenous knowledges within discrete classes or disciplines, for instance, occurs to the detriment of all learners, as Indigenous pedagogies and perspectives are thus marginalized. Until current methods and evaluations reflect Indigenous values, attempts to incorporate Indigenous ways of knowing, being, and doing into postsecondary institutions will encounter limited success.

Smith (2012) acknowledges that the 25 principles are diverse and arise from multiple disciplinary sources and experts, including "lawyers and constitutional experts," "women and health workers," and "social workers and policy analysts" (p. 143). Just as the areas that inform the creation of this model are not limited to a single discipline of research, there need be no limitation on the application of said principles. While the principles are presented as methodologies that can help Indigenous people move towards self-determination via research, it is clear that the potential for the overall philosophy is just as applicable to informing pedagogy within a university classroom. Smith (2012) argues that research "occurs in a set of political and social conditions" (p. 5), which aligns with her belief that researching is inherently a political act. We believe, following in the footsteps of critical and Indigenous educators before us, that teaching, too, is inherently political (Battiste, 2013; Freire, 2005; Kroll, 2005). Teaching and research are deeply connected, with both endeavours aimed at creating and sharing knowledge, and we find it appropriate, even fitting, to build upon Smith's principles in order to articulate Indigenous approaches to pedagogy.

Interpreting Smith's work beyond the bounds of its original scope has a strong precedent in Indigenous scholarship. To cite one example, Allen's (2012) "trans-Indigenous" framework for literary studies builds upon the critical stance that is essential to Smith's work-particularly its intention to decolonize and Indigenize academic practices. Allen (2012) suggests that Smith's work provides "a blueprint for the primary work of Indigenous studies . . . centring Indigenous concerns and perspectives within academic research paradigms and localizing Indigenous theories and analytic methodologies" (p. xx). As Allen suggests, the principles embedded in Decolonizing Methodologies constitute a theoretical framework, even a watershed moment, in Indigenous scholarship, rather than a discipline-specific methodological set. Building on this momentum, our paper investigates the application of Smith's principles in university teaching.

The intention of this section is not to argue for using Decolonizing Methodologies as the only guide for reimagining communication and engagement in a university classroom. Our purpose is to encourage more educators to recognize the opportunity for incorporating Indigenous methods and for us to contribute to this vital shift by referencing what we believe to be one of the most important texts in Indigenous scholarship. A common frustration voiced by non-Indigenous scholars is a lack of knowledge, training, or confidence to incorporate Indigenous knowledge or methods of education in their classrooms. The application of aspects of the 25 principles, as provided by the examples in this case study, is a productive place to start this important work. 


\section{In Practice}

As professors in a faculty of education, we are modelling engagement, communication, and relationship strategies, inspired by Indigenous principles, for students who will teach our future generations. If we can normalize Indigenous methods within the academy, we can begin to dismantle the status quo that uses Western perspectives and methods of education as the default. Indigenous students can become accustomed to having their ways of knowing respected in school systems, and non-Indigenous students can become accustomed to recognizing, respecting, and applying other epistemologies. The Werklund School of Education at the University of Calgary is supporting the considerable work of Indigenizing the academy through a number of strategic decolonizing initiatives. We believe that concomitant to such initiatives must be a shift in approaches to teaching and its assessment.

In what follows, we provide a case study from our own teaching in varied undergraduate and graduate courses in education: this examination illustrates how we apply Indigenous principles-framed within a selection of Smith's 25 Indigenous principles-to educational practice. We first define and explain the principles that we are addressing and then explore how we take up those principles in our classrooms. We intend these examples to inspire and create understandings of how Smith's principles are a valid pedagogical model-that is, to teach from an Indigenous pedagogy. We recognize that there are barriers within a Western structural system that will have to be overcome to facilitate full implementation of these principles, yet these nascent movements are full of much potential.

\section{Remembering, Claiming, and Connecting (Jacqueline Ottmann)}

As an Anishinaabe person, I was immediately drawn to the aspect of self-determination in Smith's (2012) framework. If I were asked to describe my life's work, I would answer, "To facilitate self-determination for Indigenous peoples and their communities." Smith's framework guides this process in a powerful way. It is important to note that Smith explains that the 25 research projects, now principles, intersect and overlap. With this in mind, I will weave the principles of remembering, claiming, and connecting, by trying to delve into each with equity. I define remembering as connecting to what has been lived, claiming as voicing what belongs in the circle, and connecting as being in "communion" with all my relations.

Our bodies inherently carry memory, memories that wait to be wakened by sound, sight, touch, or smell. Kimmermer (2013) describes the smell of sweetgrass: "Hold the bundle up to your nose. Find the fragrance ... and you will understand ... Breathe it in and you start to remember things you didn't know you'd forgotten" (p. ix). Kimmermer's example of remembering is healing. Smith (2012) explains that the form of remembering that she refers to "is painful because it involves remembering not just what colonization was about but what being dehumanized meant for our own cultural practices" (p. 147). Healing and transformation are reasons for engaging in this form of mindful remembering. There is tremendous responsibility to "all my relations" in research and teaching that asks for this-after all, this work is sacred.

Smith (2012) states that colonization in all its forms has resulted in Indigenous peoples throughout the world "making claims and assertions" (p. 144) for justice and their inherent rights. There is something wrong with this current lay of the land, but it is where we have arrived. Smith notes that acts of self determination have been "interesting and 
dynamic" (p. 144) and have included research and the "writing of nation, tribe, and family histories" (p. 144) by Indigenous people themselves for the purpose of legitimizing claims. It is not surprising that stories have been used to validate rights. Stories connect our collective past, present, and future-even time demands to be recognized as a connected braided strand: "To be connected is to be whole" (Smith, p. 149). While in high school, I had the privilege of learning my community's story through research. As a community we connected, remembered, and (re)claimed the stories of our ancestors. Eventually, these stories helped validate our specific land claim. There is power in research.

Throughout my career, I have often used "claiming" and "connecting" exercises to develop identity and leadership in students. To foster this, I have students ask, Who am I? Where do I come from? Where am I going? What are my responsibilities? These questions formed the basis of a major research project for a group of Grade 7-8 First Nations students that I was teaching. Because the students were interviewing their grandparents-the Elders and knowledge keepers of their community - this research had to be done "in a good way," so we learned their traditional Elder protocol. The students were engaged in interviewing, transcription, theme extraction, and dissemination. Through this year-long project, they were able to meaningfully claim and reclaim their place, space, and right to land.

It has been an honour to witness students transform from the struggle presented by new knowledge, or old knowledge presented in a new way. Because I have been a part of this creative, tumultuous space, I too have experienced change. It's hard not to; after all, this is sacred work. As educators, we all hold the responsibility to claim, remember, and engage in work that connects seven generations. Kimmermer (2013) asks,

Will you hold the end of the [sweetgrass] bundle while I braid? Hands joined by grass, can we bend our heads together and make a braid to honor the earth? And then I'll hold it for you, while you braid, too. (pp. ix-x)

\section{Negotiating (Dustin Louie)}

As an Indigenous scholar from the Nadleh Whut'en and Nee Tahi Buhn First Nations of northern British Columbia, infusing decolonizing principles into postsecondary education systems has been a transformational experience for me. A decolonizing practice I incorporate in my classroom seamlessly connects with the Indigenous notion of negotiating, which Smith (2012) defines as, "recognizing and working towards long-term goals" (p. 160). Indigenous definitions of negotiation emphasize relationship building and connected futures, instead of competing interests. The treaty negotiations with First Nations were riddled with deception by the Canadian government, an unthinkable violation of Indigenous principles (Miller, 2009). Smith (2012) argues that, from the Indigenous perspective, "protocols and procedures are integral to the negotiation; neglect or failure to acknowledge or take such protocols seriously can be read as a lack of commitment to both the process and the outcome" (p. 160).

The Balhats (potlatch) system of my First Nation offers an additional definition of Indigenous negotiation. As a democratic practice, the Balhats system informs social organization, serves as a governance structure, encourages the distribution of wealth, provides a safety net for vulnerable members of the community, offers a forum for sacred rituals, and mediates land and resource entitlement through collective negotiation. Ebert (2013) 
understands the potlatch system as a process "of discussion, consultation and negotiation that culminate[s] in the gathering of invited people to witness the claims of the host or hosts" (p. 22). Indigenous practices can inform the construction of democratic systems inside of university classrooms by requiring collective decision-making that extends participation through other ways of knowing.

Negotiating has been adopted in my classes by collaboratively assigning grades. In this negotiation I provide students with extensive formative feedback on their written assignments, withholding a final grade until students are given an opportunity to negotiate the merits of their submission. The historical consciousness influencing our perceptions as we enter negotiations is an inevitable barrier to true collaboration. Sensoy and DiAngelo (2012) prompt us never to forget the impact of positionality on the perceived power of students in ethical spaces, due to the intersectionality of race, gender, and other criteria of social stratification. Past experiences within our faculty have seen students expecting Indigenous courses to be less academically rigorous, based on lowered expectations of Indigenous academics. The negotiations between teacher and student can disrupt the fallacy of substandard Indigenous courses and faculty by modelling academic excellence and rigor, clearly establishing the intellectually demanding nature of education outside of the Western "standard."

Ermine's (2007) ethical spaces can inform negotiations between collaborators drawing from epistemologies that are seemingly incongruent. In order to enter negotiations between Western and Indigenous peoples, we must interrupt the cycle "of a deeply embedded belief and practice of Western universality" (p. 198). Students will enter negotiations with faculty from a place of skepticism, due to their indoctrination within the "universal" Western model of student-teacher power dynamics. Ermine (2007) believes that engagement and dialogue are imperative elements of ethical spaces developed to support the creation of "parameters for an agreement to interact modeled on appropriate, ethical and human principles" (p. 202). Co-creation of principles encourages the establishment of cooperative environments in postsecondary classrooms historically dominated by a dictatorial model.

As outlined by Smith (2012), the protocols and rituals of negotiation are the most important elements of meaningful interactions. The outcome of the negotiation, the grade, is actually the least important in the long-term implication for pedagogy. Moreover, I find that students are receptive to lower grades if the explanation is given in person. The consideration of formative feedback during the ritual of negotiation promotes critical thinking, deep reflection, and Indigenization. The process relinquishes authoritative power when the educator creates a culture that extends participation and promotes public debate (Smith, 2012). By not insisting on being the sole arbiter of assessment, naming, and defining fundamental terms and methods within the course, teachers are modelling Indigenous democratic values of negotiation. Negotiations, within this context, flatten the hierarchical structure between the educator and student, while eliminating the adversarial components of assessment. Seeing this behaviour modelled by an educator in a position of power allows student teachers to recognize the necessity of engaging with students from a humbled position. Creating classrooms that democratize basic structures through negotiation can establish a forum for honouring Indigenous and other culturesvalidating instead of denying access. 


\section{Celebrating Survival and Creating Survivance (Yvonne Poitras Pratt)}

As a Métis scholar and educator whose family roots trace back to the Red River historical homelands, I work to create a relational space "in between" worldviews. In 2009, I collaborated with community members from Fishing Lake Métis Settlement on the telling, creation, sharing, and celebration of their survival stories. This collective process-where survival stories from significant community members were intergenerationally told-has been recognized as a unique approach to the digital storytelling process (Lambert, 2013). With the blessing of local Elders to share, teach, and celebrate our stories with others, I acknowledge the work of Smith (2012) and Vizenor (2008), where survivance is defined as "the degree to which indigenous peoples and communities have retained cultural and spiritual values and authenticity in resisting colonialism” (Smith, 2012, p. 146).

In listening to digital stories from the Fishing Lake Métis, future educators are given an opportunity to hear about the past and contemporary lived experiences of the Métis people through a brief multimedia vignette that local community members have created from carefully selected photos, images, voice, video, and music. Viewers experience the oral tradition firsthand as a number of the digital stories weave Elders' voices into the telling. As an educator, I provide background context of the community and how the workshop came about, along with the unique story behind the creation of each story. In this way, the viewer / listener is made to understand the commitment and courage it took a once-silenced people to reclaim their narratives. Thus, the "nature of survivance is [viewed as] unmistakable, a narrative resistance that creates a sense of presence over absence, nihility and victimry" (Vizenor, 2010, p. 41). Survivance, as realized within a community setting and now shared in university classrooms, signals a significant transfer of decolonizing education from community to classroom.

As a foundational aspect of survivance, one of the more resilient characteristics of Indigenous peoples has been their creativity (Smith, 2012, p. 159). As a wellspring that nourishes survivance, the creative dimension calls forth "[i]magination [that] enables people to rise above their own circumstances, to dream new visions and to hold on to old ones" (Smith, 2012, p. 159). The creative realm, replete with imagination, innovation, and adaptation, has been instrumental in the ongoing survival of Indigenous peoples around the world. Today, there is increasing recognition by non-Indigenous people of the value of Indigenous thinking, particularly in areas such as the arts and the work of reconciliation, where solutions to our modern-day problems may be found within "complicated metaphors and mythic tales" (p. 160). Parallelling this recognition is Smith's emerging idea that "[c]ommunities are the ones who know the answers to their own problems" (p. 160).

As Indigenous faculty, we are tasked with the challenge of finding a way forward for all learners. Within an environment of what Simon (2000) terms "difficult learning," we are constantly convincing, cajoling, and persuading learners of the importance of this work. In many instances, my colleagues and I have noted the limitations of relying solely on print material to effect change. In an effort to move beyond print literacy, we take up a variety of teaching strategies often inspired by artistic traditions, such as deep-listening activities, sharing circles, storytelling, metaphorical representations, performance, and dance. These activities encourage students to exercise creativity and imagination where a more complex understanding of concepts often emerges. 
Equally importantly, the creative aspect of this work disrupts strongly held assumptions, stereotypes, and other barriers to learning. Students are asked to confront colonial assumptions inherent in notions of "authenticity" and to grapple with a growing awareness of how power and privilege, inherent in the power of representation, clings tenaciously to Western thought. We remind them, as with Vizenor (2010), that colonialists and other power holders "wanted an 'Indian' art that depicted traditional themes, abstract designs or representational portrayals of culture, which viewers could immediately recognize" (p. 42). We assert that stereotypical representations are part of the colonial project and are made without regard for the lived experiences and contemporary realities of Indigenous people. In sharing our lives and perspectives, nurtured with a critical and creative approach to learning, we are creating decolonizing pedagogy for all learners.

\section{Storytelling (Aubrey Hanson)}

As a Métis woman who grew up in a large family brimming with stories, I often turn to storytelling when something important needs to be shared in my classroom. Telling stories, as an Indigenous action, is about representing, understanding, and connecting. In outlining this principle, Smith (2012) emphasizes the importance of representing individual and shared perspectives through story (p. 145). Individual stories are powerful, she contends, particularly in that they "contribute to a collective story in which every indigenous person has a place" (p. 145). Stories bring people together-by bringing tellers and listeners into relationships and by sharing cultural values and beliefs (pp. 145-146). This collective quality of stories enables connections: "The story and the storyteller both serve to connect the past with the future, one generation with the other, the land with the people and the people with the story" (p. 146). These connections strengthen and sustain communities over time, enabling "conversations amongst ourselves as indigenous peoples” (p. 146). The significance of oral tradition and histories within Smith's (2012) discussion of storytelling is an essential emphasis, but the textual stories of Indigenous writers are also vital here (p. 145). Stories can transform academic work by enabling diverse understandings, shifting power dynamics, and connecting with cultures (pp. 145-146).

Storytelling in the classroom helps to create a space where individual perspectives are honoured and where understandings are generated collectively. While learning through cultural or traditional Indigenous stories is a significant form of Indigenous pedagogy (Archibald, 2008), my intent here is to address the simple kind of storytelling that transpires when teaching and learning happen through individuals' stories. It is important to me that everyone in my classroom has a voice, that everyone's perspectives and knowledge are valued. I find that meaningful stories arise naturally as part of respectful, collaborative environments. We are all teachers and learners (who are future teachers); everyone can share personal experiences through stories that embody the complexity and specificity of what it means to teach in particular places, particular times, and particular cultures. Our discussions spark stories that capture the integral elements of our learning-stories that inspire strong practices, stories that warn of trouble, and stories that open up inquiry. When stories are shared, I see how participants are able to bring their whole selves to the learning. Navigating students' diverse positioning and perspectives calls us as a learning community to respond respectfully and critically, working relationally to identify discourses and experiences of power, privilege, and marginalization. 
Storytelling is an Indigenous principle that transforms the classroom by shifting the relationships between teachers, students, and knowledge (Archibald, 2008; Battiste, 2013; Graveline, 1998; Smith, 2012). Stories are inseparable from traditional and cultural forms of Indigenous education (Archibald, 2008; Battiste, 2013; Smith, 2012); Métis scholar Fyre Jean Graveline (1998) situates storytelling at "the core" of Indigenous intellectual traditions and educational models (p. 64). Stories shared by all participants in classrooms change the usual terms of engagement in the academy, distributing power away from the instructor (Battiste, 2013, p. 184), just as stories can change the power dynamics of research (Smith, 2012). Stories demonstrate the importance of situating knowledge. Learning from stories involves understanding how truth or validity is "embedded in the actual experience," as well as how "experience is understood as particular, subjective, and contextual" (Graveline, 1998, p. 64). Listeners can understand the lesson embedded in a classmate's story, but they can also understand how that experience is rooted in particular people, places, and circumstances. The listeners can "build layers of new meaning into their own experiences" while appreciating diverse ways of knowing (Battiste, 2013, p. 184). Stories foster respectful relationships between tellers, listeners, and stories-a process that reflects and embodies Indigenous knowledges and epistemologies (Archibald, 2008; Battiste, 2013; Smith, 2012). Stories can create an environment in which learning emerges from individuals' meaningful experiences and multiple ways of knowing are honoured.

\section{Conclusions}

In this article, we have shared possibilities for Indigenous pedagogies from our own practice, arguing that Smith's (2012) 25 principles offer one response to the "standard" education model so ubiquitous in teacher education. These examples from our faculty highlight the potential for innovative teaching methods that contribute to the larger project of Indigenizing the academy for the benefit of Indigenous and non-Indigenous students. We see important connections between the kinds of change that can occur in everyday, small-scale, and often personal ways in our classrooms, and the larger-scale change that institutional leadership is striving for over a longer term.

In exploring our own practices, we encounter a number of questions about such change. What is the relationship between micro practices in the classroom and macro changes at the institutional level: how do they influence each other, and how is each a motivator of change? For instance, what dynamics exist between instructors, working to embody Indigenous perspectives and enact change in their university teaching, and the leadership in those universities, working to precipitate change in policies, structures, staffing, and strategic directions? How do these institutional changes impact our wider communities, if at all? What implications exist for assessment, if pedagogy is to be rooted in Indigenous principles and beliefs? How is the work of Indigenizing pedagogy or of embodying Indigenous perspectives in the classroom, to be "counted" amidst institutional systems of evaluation for performance and promotion? What avenues exist for community engagement and input within individual instructors' approaches to teaching? How will Indigenizing practices in faculties of education shape and be shaped by related processes in elementary and secondary schools? As postsecondary institutions across our nation take up the work of Indigenizing, each in their own way, we invite colleagues to consider these and other emerging questions, as we also intend to do. 
The University of Calgary campus is on traditional Blackfoot territory, and its institutional leadership is making serious strides toward respecting the members and cultures of local Indigenous communities. Changing the institution through Blackfoot protocol and traditions-in tandem with other Indigenous ways of knowing-is one way of modelling and practising respect for the traditional peoples of this land. As we have argued, pedagogy is a crucial site for such change. The practices we have shared, based upon our own experiences as Indigenous educators in the Werklund School of Education, align with Smith's (2012) principles, which are ways for Indigenous communities to work for self-determination. Applying these principles beyond the realm of research expands the influence of transformative Indigenous methodologies. Universities need this transformation, as Indigenization is too often limited to content. As scholars who have been invited to precipitate change in our university, we in turn invite our discipline to imagine the change that can be kindled by unsettling Eurocentric teaching and by Indigenizing pedagogical practice.

\section{References}

Allen, C. (2012). Trans-Indigenous: Methodologies for global Native literary studies. Minneapolis, MN: University of Minnesota Press.

Anuik, J., \& Gillies, C. (2012). Indigenous knowledge in post-secondary educators' practices: Nourishing the learning spirit. Canadian Journal of Higher Education 42(1), 63-79.

Archibald, J.-A. (2008). Indigenous storywork: Educating the heart, mind, body, and spirit. Vancouver, BC: UBC Press.

Association of Canadian Deans of Education. (2010). Accord on Indigenous education. Retrieved from http://www.csse-scee.ca/docs/acde/acde_accord_indigenousresearch_ en.pdf

Battiste, M. (1998). Enabling the autumn seed: Toward a decolonized approach to Aboriginal knowledge, language, and education. Canadian Journal of Native Education, 22(1), 16-27.

Battiste, M. (2002). Indigenous knowledge and pedagogy in First Nations education: A literature review with recommendations. Ottawa, ON: Apamuwek Institute.

Battiste, M. (2013). Decolonizing education: Nourishing the learning spirit. Saskatoon, SK: Purich.

Beran, T., Violato, C., Kline, D., \& Frideres, J. (2005). The utility of student ratings of instruction for students, faculty, and administrators: A "consequential validity" study. Canadian Journal of Higher Education, 35(2), 49-70.

Cajete, G. (1994). Look to the mountain: An ecology of Indigenous education. St. Durango, CO: Kivaki Press.

Crowshoe, R., \& Manneschmidt, S. (2002). Akak'stiman: A Blackfoot framework for decision-making and mediation processes. Calgary, AB: University of Calgary Press.

den Heyer, K. (2015). An analysis of aims and the educational "event." Canadian Journal of Education, 38(1), 1-27. Retrieved from http://ezproxy.lib.ucalgary.ca/ login?url=http://search.proquest.com/docview/1681254008?accountid=9838 
Ebert, M. (2013). Feasting judicial convergence: Reconciling legal perspectives through the potlatch complex. Appeal, 18(21), 21-35.

Ermine, W. (1995). Aboriginal epistemology. In J. Barman \& M. Battiste (Eds.), First Nations education in Canada: The circle unfolds (pp. 101-112). Vancouver, BC: UBC Press.

Ermine, W. (2007). Ethical space of engagement. Indigenous Law Journal, 6(1), 193203.

Freire, P. (2005). Pedagogy of the oppressed. New York, NY: Continuum.

Gilbert, G. (2005). "Catching the knowledge wave": Redefining knowledge for the post-industrial age. Education Canada 47(3), 4-8. Retrieved from http://www.cea-ace. ca/sites/default/files/EdCan-2007-v47-n3-Gilbert.pdf

Giroux, H. (2014a). When schools become dead zones of the imagination: A critical pedagogy manifesto. Policy Futures in Education, 12(4), 491-499.

Giroux, H. (2014b). Neoliberalism's war on higher education. Chicago, IL: Haymarket Books.

Goulet, L. M., \& Goulet, K. N. (2014). Teaching each other: Nehinuw concepts and Indigenous pedagogies. UBC Press.

Graveline, F. J. (1998). Circle works: Transforming Eurocentric consciousness. Halifax, NS: Fernwood.

Gredler, M. E. (2005). Learning and instruction: Theory into practice. Upper Saddle River, NJ: Pearson / Merrill Prentice Hall.

Hardes, J. (2013). Retention of Aboriginal students in post-secondary education. In F. Widdowson \& A. Howard (Eds.), Approaches to Aboriginal education in Canada: Searching for solutions (pp. 247-255). Edmonton, AB: Brush Education.

Kimmermer, R. W. (2013). Braiding sweetgrass: Indigenous wisdom, scientific knowledge, and the teaching of plants. Minneapolis, MN: Milkweed Editions.

Kincheloe, J., \& Steinberg, S. (2007). Cutting class: Socioeconomic status and education. Lanham, MD: Rowman \& Littlefield.

Kovach, M. E. (2010). Indigenous methodologies: Characteristics, conversations, and contexts. University of Toronto Press.

Kroll, L. (2005). Teaching as principled practice: Managing complexity for social justice. Thousand Oaks, CA: SAGE.

Lambert, J. (2013). Digital storytelling: Capturing lives, creating community (4th ed.). New York \& London: Routledge Press.

Little Bear, L. (2000). Jagged worldviews colliding. In M. Battiste (Ed.), Reclaiming Indigenous voice and vision (pp. 77-85). Vancouver, BC: UBC Press.

Little Bear, L. (2009). Naturalizing Indigenous knowledge: Synthesis paper. Saskatoon, SK: University of Saskatchewan, Aboriginal Education Research Centre.

Little Bear, L. (2011). Native science and Western science: Possibilities for a powerful collaboration. Phoenix, AZ: Simon Ortiz and Labriola Center Lecture on Indigenous Land, Culture, and Community. Retrieved from https://www.youtube.com/ watch?v=ycQtQZ9y3lc 
Merriam, S. B. (1998). Qualitative research and case study applications in education (Rev. ed.). San Francisco, CA: Jossey-Bass.

Miller, J. R. (2009). Compact, contract, covenant: Aboriginal treaty-making in Canada. Toronto, ON: University of Toronto Press.

Nath, J. (2005). The roles of case studies in the educational field. International Journal of Case Method Research \& Application, XVII(3), 396-400. Retrieved from http://www. wacra.org/PublicDomain/IJCRA\%20xvii_iii\%20Nath.pdf

Pidgeon, M., Archibald, J-A., \& Hawkey, C. (2014). Relationships matter: Supporting Aboriginal graduate students in British Columbia, Canada. Canadian Journal of Higher Education 44(1), 1-21.

Pepion, D. (1999). Blackfoot ceremony: A qualitative study (Doctoral dissertation). Montana University, Bozman, Montana.

Porsanger, J. (2004). An essay about Indigenous methodology. Nordlit, 8(1), 105-120.

Rogers, C., \& Freiberg, H. (1994). Freedom to learn. New York, NY: MacMillan College Press.

Schissel, B., \& Wotherspoon, T. (2003). The legacy of school for Aboriginal people: Education, oppression, and emancipation. Don Mills, ON: Oxford University Press.

Sensoy, Ö., \& DiAngelo, R. (2012). Is everyone really equal? An introduction to key concepts in social justice education. New York, NY: Teachers College Press.

Simon, R. (2000). The touch of the past: The pedagogical significance of a transactional sphere of public memory. In P. Trifonas (Ed.), Revolutionary pedagogies: Cultural politics, instituting education, and the theory of discourse (pp. 61-80). New York, NY: Routledge.

Smith, L.T. (2012). Decolonizing methodologies: Research and Indigenous peoples (2nd ed.). New York, NY: Zed Books.

Spafford, M. M., Nygaard, V. L., Gregor, F., \& Boyd, M. A. (2006). "Navigating the different spaces": Experiences of inclusion and isolation among racially minoritized faculty in Canada. The Canadian Journal of Higher Education, 36(1), 1.

Statistics Canada. (2011). National housing survey: Aboriginal people in Canada. Ottawa, ON, Catalogue number 11-001-x

Stonechild, B. (2006). The new buffalo: The struggle for Aboriginal post-secondary education in Canada. Winnipeg, MB: University of Manitoba Press.

Truth and Reconciliation Commission of Canada. (2015). Truth and Reconciliation Commission of Canada: Calls to action. Retrieved from http://www.trc.ca/websites/ trcinstitution/File/2015/Findings/Calls_to_Action_English2.pdf

University of Alberta. (2011). Dare to deliver 2011-2015: The academic plan for the University of Alberta. Retrieved from http://uofa.ualberta.ca/-/media/ualberta/ president/dare-to-discover-docs/d2dacademicplan-2011-2015.pdf

University of Alberta. (2015). Universal student rating of instruction. Retrieved from: https://ist.ualberta.ca/services/tsqs/universal-student-ratings-instruction 
University of British Columbia. (2012). Place and promise: The UBC plan. Retrieved from http://strategicplan.sites.olt.ubc.ca/files/2009/11/UBC-PP-Layout-Aug2012.pdf

USRI Review Committee. (2003). The Universal Student Ratings of Instruction instrument and the University of Calgary: A review of a three year pilot project. Calgary, $\mathrm{AB}$ : University of Calgary.

Vizenor, G. (2008). Survivance: Narratives of Native presence. Lincoln, NB: University of Nebraska Press.

Vizenor, G. (2010). American Indian art and literature today: Survivance and tragic wisdom. Museum International, 62(3), 41-51. doi: 10.1111/j.1468-0033.2010.01732.x

Yin, R. K. (2009). Case study research: design and methods. essential guide to qualitative methods in organizational research (fourth edition). Thousand Oaks, CA: Sage

\section{Contact Information}

Dustin William Louie

Werklund School of Education

University of Calgary

dwlouie@ucalgary.ca

Dustin William Louie is an Indigenous scholar from the Nadleh Whut'en and Nee Tahi Buhn First Nations, a member of the Beaver Clan. As a tenure-track assistant professor at the Werklund School of Education, he teaches courses primarily related to Indigenous education, diversity, and educational philosophy. Dustin's dissertation examined sexual exploitation preventation education for Indigenous girls in northern Saskatchewan. Currently, he is undertaking a three-year follow up study in Calgary, funded by the Alberta Human Rights Commission, which will see research findings translated into preventation programming for on-reserve schools. Further research interests include decolonizing education, social justice education, and critical theory.

Yvonne Poitras Prattt is a Métis scholar and tenure-track assistant professor at the Werklund School of Education. She has taught the mandatory Indigenous education course to pre-service teachers over the past four years, and in 2016, she worked collaboratively to launch a graduate program for adult learners focused on reconciliation efforts. Supported by federal scholarships, Yvonne's dissertation focused on digital storytelling as a decolonizing means whereby oral traditions and intergenerational learning were revitalized within Métis communities. Her research interests now extend to reconciliatory pedagogy, critical service-learning, anti-racism and social justice studies, along with the integration of arts in education.

Aubrey Jean Hanson is of Métis, German, and Icelandic ancestry and is from Calgary, Alberta. She is a tenure-track assistant professor in Curriculum and Learning program at the Werklund School of Education at the University of Calgary. Aubrey's research and teaching focus upon Indigenous education, curriculum studies, Indigenous literatures, and social justice education. Her writing has been published in Studies in American In- 
dian Literatures and The Walrus. Before undertaking doctoral studies, Aubrey was a high school teacher in Calgary and Toronto.

Dr. Jacqueline Ottmann is Annishinabe (Saulteaux), originally from Saskatchewan. After years of elementary and secondary teaching in public, separate, and private systems in Saskatchewan and Alberta, and a principalship, Jacqueline entered the graduate program at the University of Saskatchewan where she received her MEd and PhD, after completing research on First Nations leadership and spirituality and First Nations leadership development. Dr. Ottmann is now the Vice-Provost of Indigenous Engagement at the University of Saskatchewan. Ottmann has instructed in both the teacher preparation and the graduate program at the University of Calgary since 2004. She has also presented at educational conferences and has established collaborative research, scholarly and educational relationships in Canada, the United States, New Zealand, and Australia. 